\title{
Developing insights into the link between art and tourism through the value co-creation lens
}

\author{
Özge Gökbulut Özdemir \\ Business School, Ankara Yildirim Beyazit University, Ankara, Turkey \\ Ian Fillis \\ Liverpool Business School, Liverpool John Moores University, Liverpool, UK, and \\ Ayşe Baş Collins \\ School of Applied Technology and Management, Bilkent University, Ankara, Turkey
}

Insights into

link between art and tourism

Received 30 January 2020 Revised 19 June 2020 Accepted 22 July 2020

\begin{abstract}
Purpose - The aim of the study is to gain insight into the link between art and tourism from a value co-creation perspective. This link is discussed with the help of the arts marketing, art tourism and value co-creation literature. The role of art in tourism and the role of cultural places in arts marketing are also evaluated.

Design/methodology/approach - Focussing on two cultural heritage sites in Turkey, Zeugma and Göbeklitepe, a qualitative study was undertaken in order to determine the value creation and co-creation processes occurring from the art-tourism contexts based on comparative case study analysis. In-depth semistructured interviews were conducted with three groups of actors. Motivation, expectation and stakeholder experiences were the main themes explored.

Findings - The findings of the study relate to the role of the co-creation process. Marketing art in alternative places creates value in closing the gap between art and society through the use of related fields such as culture and heritage. In terms of cultural value, the paper identifies the reconnection with cultural heritage through contemporary art. This is a way of looking at culture and its concepts in different time and place dimensions which make visitors more engaged with culture and its contemporary reflection through art.

Research limitations/implications - Although the research focusses on two Turkish art and tourism cases, future research can be extended to other countries, including the assessment of the longer-term role of similar activities.

Practical implications - As art is a subset of culture, the people who are interested in culture and history also have the potential to be interested in art. While art impacts on cultural tourism, cultural heritage and tourism work as arts marketing tools in a co-supporting way. The coming together of art and culture has societal benefits. There are lessons for practice such as the opening of a space for contemporary art in cultural heritage museums in order to promote art to society. The museum audience is an important potential for the future of art from a market generation perspective.

Originality/value - The study contribute to arts tourism, arts marketing and value co-creation in theory and practice.
\end{abstract}

Keywords Art tourism, Arts marketing, Value co-creation, Authenticity, Cultural value

Paper type Research paper

\section{Introduction}

Although art tourism is attracting attention as a relatively new field in tourism studies; in practice, it is as old as tourism itself since art and culture have been a focal interest of society for centuries. Franklin (2018, pp. 399-400) views art tourism as:

any activity that involves travel to see art and would include those people who travel very specifically to see art somewhere else as well as those who often or occasionally include visits to see art among other activities during tours, holidays or other trips away from home.

The writing process of the paper was completed during the term that Özge Gökbulut Özdemir was in Liverpool John Moores University through the support of TÜBITAK (the Scientific and Technological Research Council of Turkey) 2219 Scholarship Programme.
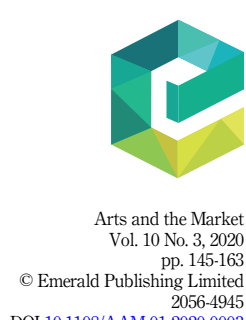
DOI 10.1108/AAM-01-2020-0003 
However, it is currently discussed mostly under "cultural tourism's voluminous bounds" 10,3 (Franklin, 2018, p. 399). This new research field, instead, has the opportunity to review the unavoidable change, growth and development in global tourists' demography and their tastes from national and international perspectives. There has, however, been some research applying new methodologies and perspectives connecting art and tourism. Tribe (2008, p. 941), for example, in his study concerning the collection of 900 artworks, described "some aspects of tourism that are beyond the reach of words". With tourism as a topic for artists to explore, there are limitations in examining only language and text as representations of the world. Instead, we are now seeing a move towards the visual which now becomes a form of text. This entails a shift from literal interpretation to now include, for example, the symbolic, our impressions and use of imagination.

Debates on the meaning of art and cultural tourism are ongoing because of the sophisticated nature of art and culture (e.g. Richards, 2007; Richards, 2018). The aim of this study is to provide insight into the link between art and tourism in terms of adding value to each other from theoretical and practical perspectives. The contribution of this study relates to the extension of knowledge by bringing together the art and tourism dimensions that have not previously been examined holistically. The main research questions focus on the following: "How does art create value for tourism? How do touristic destinations create value for art? and "How does co-creation occur within these settings?" We extend our understanding of art and tourism co-creation through our comparative analyses of two Turkish cases: Zeugma and Göbeklitepe.

The paper is structured as follows: the literature review is developed on value co-creation from cultural value, art and tourism perspectives. Next, we discuss our qualitative case study methodology. We then present our findings, followed by our discussion and conclusions.

\section{Value in marketing: from exchange to value co-creation}

With the evolution of marketing theory, "value" emerged as the centre of the exchange process, with the American Marketing Association (2004) defining marketing as "value creation" but still just mentioning one side that creates "value" to the other side. This narrow supply side view was criticized because it ignored active consumers' and marketing's societal impact involving all stakeholders (Sheth and Uslay, 2007). Recently, attention has shifted towards "value co-creation", for example (Prahalad and Ramaswamy, 2004; Sheth et al., 2000).

In understanding the cultural value associated with an art tourism site and the consumption of the related experience, we can view this as involving both interpretation and realization as a form of co-creation (Eco, 1977). This involves the processes by which both consumers and producers collaborate, or otherwise participate, in creating value in a coconsuming brand community (Pongsakornrungsilp and Schroeder, 2011, p. 304). We experience art tourism both passively and actively as we consume through absorption and immersion, signalling the co-creation of value (Vargo and Lusch, 2004; Gronroos, 2012). This has increasingly been viewed through a service-dominant (S-D) logic lens (e.g. Benpaudi and Leone, 2003; Solveig, 1996; Lusch and Vargo, 2006). If we view co-creation as the basis for innovation and value creation, there is growing representation of tourism studies in this area (e.g. Binkhorst and Den Dekker, 2009; Prebensen and Foss, 2011; Bertella, 2014; Andrade and Dimanche, 2014), and our work therefore contributes to expanding this knowledge base. Campos et al. (2018) identify a broad range of publications containing tourism co-creation studies, but these are generally only one paper per journal, with only higher-quality outlets such as Annals of Tourism Research and International Journal of Tourism Research containing greater numbers. Even then these are still in single figures. Examples of cocreation between the cultural tourist and the site include contributing to the overall tourism experience, taking part in on-site experience-based activities and interacting with others at 
the site (Campos et al., 2018). These authors also construct a definition of on-site co-created tourism experience:

a co-creation tourism experience is the sum of the psychological events a tourist goes through when contributing actively through physical and/or mental participation in activities and interacting with

other subjects in the experience environment (p. 391).

Thus, service provision and the co-creation of value imply that exchange is relational and both sides are active participants of the process in the service-centred model (Lusch and Vargo, 2014). S-D logic is differentiated from traditional goods-centred logic by determining the meaning of the value:

Value is perceived and determined by the consumer on the basis of "value in use" opposed to "Value is determined by the producer. It is embedded in the operand resource (goods) and is defined in terms of "exchange-value". (Lusch and Vargo, 2014, p. 7).

As mentioned earlier, all these discussions on value co-creation resulted in the development of the S-D logic approach. However, S-D logic needs more evidence-based research (Vargo and Lusch, 2017, p. 64) and improvement for (1) a cohesive general theory (2) a more specific, empirically testable and practically applicable, midrange theory and (3) more influence from diverse disciplines and research streams and emerging micro-level research initiatives and lastly, more scholars who find the S-D logic perspective useful for their work.

\section{Forms of value in tourism}

Recently, there has been an emerging trend for concentrating on value retention, value creation and value co-creation within the sector in order to maximize economic benefits, business development, planning and strategies (Lin et al., 2017; Reichenberger (2017). The question here is "how is value defined in art and tourism?" It might sound complicated, as McGarry (1998, p. 50) states "if defining value is a difficult exercise, then creating it can be more challenging". The issue here relates to how we can create value and what does value creation mean in this context.

From the lens of one of the earliest value chain models (Porter, 1985), value creation can be achieved by identifying and understanding customer benefits, costs and the combination of the company's activities. Contrary to this, Norman and Ramirez (1998) emphasize the relationship between different actors in order to start co-producing the value. Another perspective by Prahalad and Ramaswamy (2004) views value as having unique personalized experiences by an individual customer.

Porter's (1990) diamond theory of national advantage was applied to tourism destinations by Fabricus (2001). He emphasized that some tourism industry characteristics should be taken into consideration during this process since (1) the primary tourism product is not a tangible product or service but an experience where the discretion, tastes and attitudes of the consumers are important; (2) the tourism market is confronted with a "virtual" proposal often in the form of pictures, descriptions and perceptions based on media exposure and personal interactions; and (3) the tourism experience is not a finished product (Tajzadeh-Namin, 2012). Therefore, the role of consumers in this experience-based sector is highly important in value creation and co-creation since they are not passive participants; instead, they are the producers of their own experiences (Sandström, Edvardsson, Kristensson and Magnusson, 2008) in being the resource integrators in those destinations (Arnould et al., 2006; Vargo and Lusch, 2004). In this framework, co-creating experiences before, during and after a vacation requires interaction with other people and with products and services in various servicescapes (Bitner, 1992). This process may lead to increased or decreased value for consumers and other actors. This is an "interactive, relativistic, preference experience" (Holbrook, 2006, p. 715) achieved through the emotional state of consumption (Kim, 2012). 
We have already stated that art tourism research is underdeveloped and by addressing this 10,3 gap in knowledge, we contribute to understanding how co-created experiences help to enhance the value dimensions associated with it.

\section{Understanding the contribution of cultural value}

One way of interpreting how culture is expressed is via systems of production and through the dissemination of cultural messages inherent in products or services. This can, of course, be relative and subjective as we tend to individualize and share this value as cultural consumers (Walker and Chaplin (1997). The understanding of cultural value by governments, cultural institutions, funders and other stakeholders is growing in importance. To date, the majority of research has adopted an instrumental, economic position so that governments can record or "measure" the value of cultural activities and experiences (e.g. Bonus and Ronte, 1997; Throsby, 2003). However, the problem with this approach is that cultural value's intangible, qualitative attributes are ignored, which is why we utilize a qualitative approach in this research. Although there is a lack of consensus on defining cultural value, there is agreement that it actively contributes to making change happen (O'Brien and Lockley, 2015). Crossick and Kaszynska (2014, p. 124) do attempt to define it by viewing cultural value as:

...the effects that culture has on those who experience it and the difference it makes to individuals and society.

Throsby (2003, pp. 279-280) makes an alternative interpretation of its essence:

...The characteristics of cultural goods which give rise to their cultural value might include their aesthetic properties, their spiritual significance, their role as purveyors of symbolic meaning, their historic importance, their significance in influencing artistic trends, their authenticity, their integrity, their uniqueness, and so on.

Holden (2006, pp. 14-18) views cultural value as a triangular relationship concerning intrinsic, instrumental and institutional values where:

Intrinsic values. . relate to the subjective experience of culture intellectually, emotionally and spiritually... Instrumental values relate to the ancillary effects of culture... to achieve a social or economic purpose. . Institutional value relates to the processes and techniques that organisations adopt in how they work to create value for the public. . .

Throsby's definition identified the intangible elements of cultural value not seen in cultural economics interpretations. It also begins to break down its essence into a number of sublevels. Holden has extended this by visualizing the value relationships as a way of also enhancing our understanding of both hidden and tangible elements. In our research, we acknowledge these different dimensions and their impact on the groups of actors involved in helping to explain the value co-creation process.

In marketing terms, cultural value can be seen in a variety of forms, from the communication of messages and other statements relating to art and tourism objects, to the activities and experiences relating to the consumption of the site itself. Clearly, cultural value in this sense is much more than purely economic as it has the potential to enhance knowledge and understanding. Remembering and reflecting on a visit can be just as important as the actual visit itself.

\section{Cultural tourism nostalgia and authenticity}

Reflecting and remembering connect with the concepts of nostalgia and authenticity which we now discuss in conjunction with the sense of aura and co-creation. Benjamin (1970/1936) notes how the presence of the original object, together with its physical location, produces an 
aura or halo of significance. Co-created aura values also occur as the visitor interacts with the object (Levi-Strauss, 1969). The values associated with the product are tangibilized through the visitor's aesthetic sensing processes (Bjorkman, 2002). This sense of aura, which also includes the sense of the past or atmosphere, contributes to the perceived authenticity of the object (Newman et al., 2011; Rickly-Boyd, 2012; Dorrian, 2014). There is a sense of authenticity being experienced by visitors in the museum shop, for example, as they view and purchase reproductions via the "authentic" reproduction process.

Bjorkman (2002) views aura as an emotionally charged experience, often connecting with the past. This then impacts on how we might perceive the object's authenticity. Art and cultural tourism consumers look for authenticity in their quest to escape from modern life (MacCannell, 1976). Aura production is shaped by customer valuations, media relationships, marketing strategy, intuition levels and aesthetic knowledge. The aura moves beyond conventional product characteristics in appearing to become part of the self through its ability to flow around a space (Benjamin, 1999).

Nostalgia involves a sense of longing for the past (Holbrook, 1993) while simultaneously holding a negative perception of the present and future (Holbrook and Schindler, 1991). Nostalgia involves self-exploration and sense-making, being much more than an aesthetic or cultural tour of the past (Jafari and Taheri, 2013). This sense-making can also be aided through the co-creation activities discussed in this paper. The growth in interest in nostalgiabased tourist sites is driven by growing levels of urbanism compared to a much greater historical rural platform, resulting in yearning for a lost past (Dann, 1998; Brown, 1999). We do not necessarily have to experience the past in order to feel nostalgic, as long as we can have access to it through, for example, film, retailing and heritage (Goulding, 1999).

Schouten (2007) investigated the connection between cultural tourism and authenticity, identifying both positive and negative impacts due to globalization effects, ranging from the revival of the local economy and its cultural traditions through to selling crafts to tourists and ignoring local needs. If tourists need to travel some distance to the destination, this then enhances the authenticity of the cultural experience in differentiating what is consumed and experienced at the site compared with everyday consumption (MacLeod, 2006). There are also differences in authenticity when we compare and contrast perceptions by the visitor (the "guest" perspective) and those based at the destination (the "host" perspective).

In summarizing the key insights from the literature review, we can see that value, and more specifically, cultural value, is a complicated concept containing a range of both tangible and intangible elements. In the context of the value of art to tourism and the value of tourism to art, co-creation helps to shape the processes involved. There is potential for collaboration between visitors, artists and, in the following comparative case study, the cultural site itself. More specifically, the value of tourism to art has the potential to introduce new audiences to an exhibition, including those who have never previously visited an art display. In discussing these relationships, this further strengthens the aim of our study in obtaining insight into the co-creation connections between art and tourism.

The cases we have selected for examination are not just historic sites of interest to cultural tourists. They are also being utilized by artists in the development of their work as they become influenced by the cultural experience. Hence, there is a dual transference between the impact of tourism on art and the impact of art on tourism.

\section{The case study research: Zeugma and Göbeklitepe}

Two cases, namely Zeugma and Göbeklitepe cultural heritage sites, were chosen in order to determine the value creation and co-creation processes occurring in art tourism. The former is one of the largest mosaic museums in the world and hence offers ample opportunity to examine the relationships between art and tourism. The latter is another site of significant 
AAM 10,3

150

importance as it has the potential to impact on how we understand an important stage of the development of society. The two sites involved have art exhibitions which create added value for both art and tourism experiences. Not only are the two sites of historical and cultural importance but that the involvement of tourists and artists now being additional dimensions to bear in terms of contemporary co-creation activities. Before setting out the details on methodology, the following section provides an overview of the case subjects.

\subsection{Zeugma Mosaic Museum as both cultural value and art exhibition}

Zeugma, in Turkey's Gaziantep Province, has been considered a UNESCO World Heritage site since 2012. Its archaeological remains are from the period between the 1st century BCE (the time of Antiochus, King of Commagene) and the 3rd century CE, when the city was sacked by the Sasanian King Shapur in $253 \mathrm{CE}$. The remains reflect the complicated, sometimes ambiguous, yet extremely varied character of the ethnicities once located there. Zeugma is defined as a first- and third-degree archeological site. The first scientific excavations within Zeugma started in 1987 (See Plate 1). The collection of Zeugma Mosaic was transported to the Zeugma Mosaic Museum in Gaziantep (See Plate 2), which is the second largest museum of its kind in the world. The outstanding artistic quality of the main exhibits is revealed in the collections of Late Antiquity Church Mosaics and Early Chaldean and Christian iconography. Amongst the most exciting archaeological finds of our times, the

Plate 1.

Zeugma excavations

Plate 2.

Zeugma mosaic museum
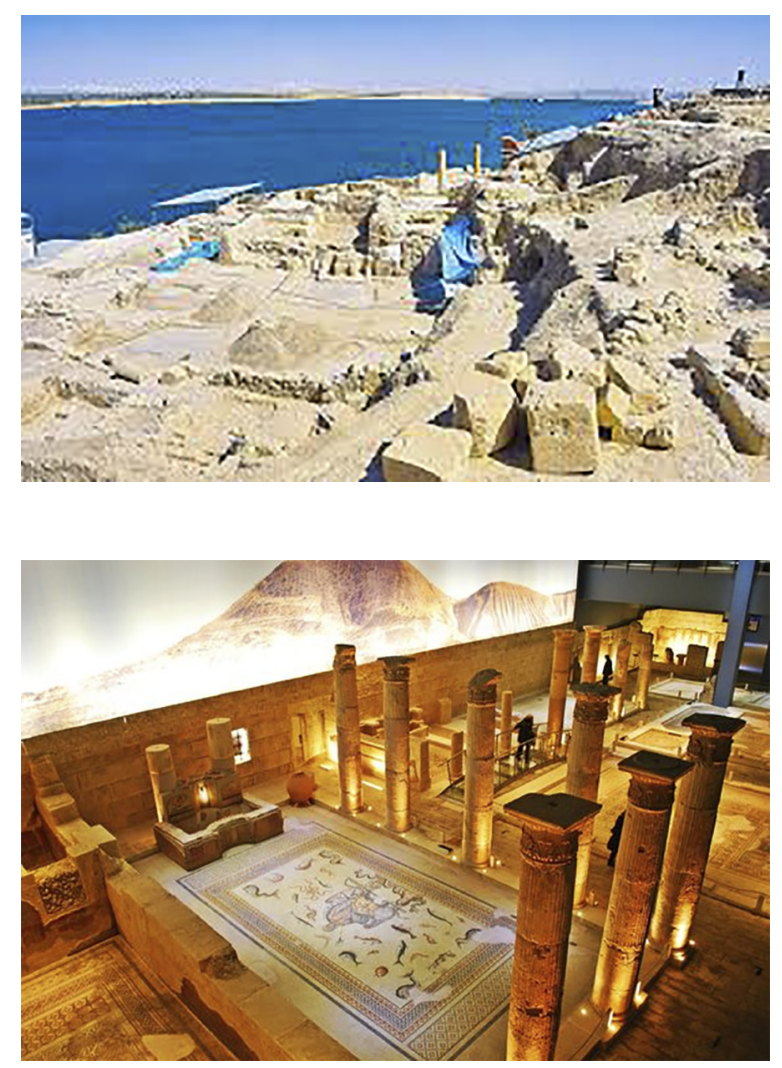
mosaics unearthed in Zeugma ancient settlements cover a total of 2,500 square metres and display the highest level that the arts had reached at that time (http://www.zeugma.org.tr/). The symbol of the ancient city and the museum is "The Gypsy Girl" from the 2nd century and its popularity can be seen in it being known as the Mona Lisa of Zeugma. The Gypsy Girl is the only remaining part of the floor mosaic of the dining room of the Maenad Villa.

6.2 Göbeklitepe as cultural heritage and art exhibition in ARMADA shopping mall, Ankara

Göbeklitepe (or Potbelly Hill) is an archaeological site in the Southeastern Anatolia Region of Turkey, approximately $12 \mathrm{~km}$ northeast of the city of Şanlıurfa. The tell, or artificial hill, has a height of $15 \mathrm{~m}$ (49ft) and is about $300 \mathrm{~m}$ (980ft) in diameter. Göbeklitepe, which was not used as a settlement and served only as a temple, entered the UNESCO World Heritage List in 2018 due to its spectacular architecture. 2019 was announced as "Göbeklitepe Year" in Turkey. Even though only a small part of Göbeklitepe has been excavated, it has still impacted on the timeline of civilization with its history of about 12000 years. Göbeklitepe, considered to be the oldest and largest ritual site in the world, demonstrates the effect of religious belief on the transition to a settled life.

Although a limited portion of this prehistoric settlement was excavated in the Harran Plain, its unusual findings have altered existing perspectives on the Neolithic Age. The most interesting findings at Göbeklitepe are the t-shaped monolithic pillars weighing 40 tons and reaching up to $6 \mathrm{~m}$ in length (See Plate 3). Even though only six of these pillars were excavated, geomagnetic measurements found that there are around 20 in total. They were originally lined up in a circle with stone walls in between. There is also a pair of large pillars in the centre of the structure. Most have human, animal or abstract symbols on their surface (See Plate 4). The pillars with hand, arm and finger motifs on the body have been interpreted as human statues.

\subsection{Methodology}

A comparative qualitative case study analysis (Silverman, 2016; Yin, 2014) was undertaken in order to determine the value creation and co-creation processes occurring from an arttourism context. This enabled exploring, prompting and probing of respondents to be carried out. The case study approach enables multiple levels of analysis to be carried out. Similarities and differences can be identified through cross-case patterns (Seawright and Gerring, 2008). This form of an empirical inquiry investigates a contemporary phenomenon in depth and from a real-life context where the boundaries between phenomenon and context are not clearly evident. It is particularly useful in under-researched areas (Eisenhardt, 1989) where existing theory is inadequate.

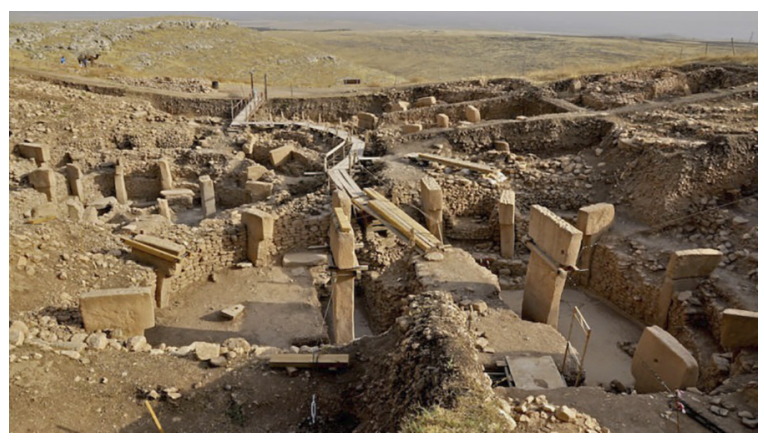

Plate 3. Göbeklitepe excavations 


\section{AAM 10,3}

\section{2}

Plate 4.

Göbeklitepe stones

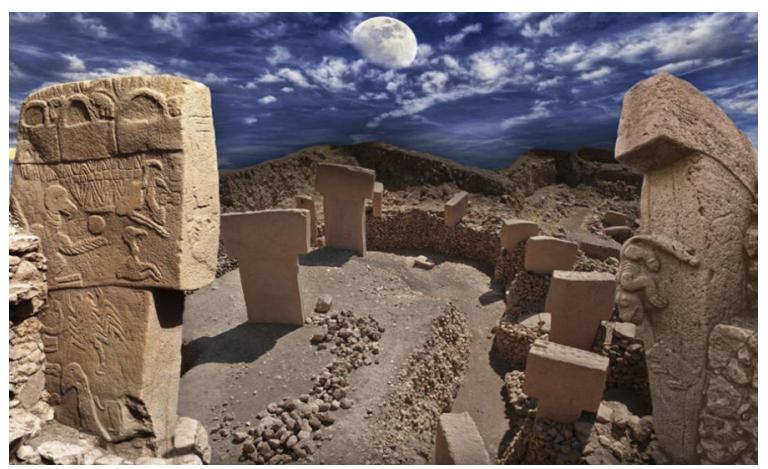

With case 1, a group of artists exhibited their artwork in an exhibition at Zeugma. The exhibition lasted two weeks. The artists also visited the Zeugma museum. With case 2, an exhibition was held in the Armada shopping mall in Ankara as part of Göbeklitepe Year. The study aimed to uncover the motivations, expectations, experiences and opinions of the different actors involved with the two sites, such as painters, tourists, event organizers and local people who all participated in this value co-creation process (See Figure 1).

We were able to investigate the phenomenon through different viewpoints as per Rosenberg and Yates (2007). Our study data was derived from (1) semi-structured interviews with stakeholders; (2) site visits and observations by two researchers; (3) reviews of secondary data such as websites, policies, legislation, promotional materials, annual reports and internal documents.

6.3.1 Sampling. Purposive sampling was applied since our study designs involved multiple phases, with each phase building on the previous one (Sharma, 2017). In-depth semistructured interviews were conducted with three groups of actors in both cases. Motivation, expectation and stakeholder experiences were the main themes of the semi-structured indepth interviews. The first group consisted of the artists attending the exhibition and the tourism event in Zeugma Mosaic Museum and the Göbeklitepe exhibition in a mall in Ankara. The second group was comprised of tourists and other visitors at the Zeugma Mosaic Museum and the Göbeklitepe Cultural Heritage Site. The third group was composed of the organizers of the art tourism events in Zeugma and Göbeklitepe, the managers of the museum and the personnel responsible for the Göbeklitepe exhibition at the mall in Ankara.

6.3.2 Data collection. Data were collected through semi-structured interview schedules prepared for each participant group. The questions explored: (1) their motivation for the trip, (2) their expectations and satisfaction, (3) their thoughts about the value creation between the art exhibition and cultural sites, (4) their suggestions for improving value creation between art and cultural heritage. The breakdown of interviews by respondent type was (1) artists attending the exhibition and the tourism event in Zeugma Mosaic Museum $(n=20)$ and Göbeklitepe $(n=10)$; (2) tourists and other visitors of Zeugma Mosaic Museum and the exhibition $(n=18)$ and Göbeklitepe $(n=5)$; the organizers of the art tourism events in

Figure 1.

Actors of the Zeugma co-creation process
Artists (attending the art exhibition)

Tourists/visitors of the event and the museum 
Zeugma and the managers of the museum $(n=3)$ and Göbeklitepe $(n=2)$. Additional data, as mentioned previously, was collected via 2) participant observations and 3) reviews of secondary data. The findings were then triangulated in order to ensure consistency and rigour in our analysis. Table 1 visualizes the process followed.

The interview schedule ensured consistency between the two researchers. The primary objective was to encourage participants to lead the conversation in a manner that was important to them when recounting their experiences. Participation in the study was voluntary. The interviews lasted around 40-50 min each and were digitally recorded and transcribed. Data collection continued until data saturation was achieved (Fusch and Ness, 2015).

6.3.3 Data analysis. The data was analysed in order to identify the main categories of value creation with respect to art and tourism. Two researchers conducted thematic analysis (Boyatzis, 1998) until the first- and second-order categories and themes emerged. The interview data was triangulated with the observations from site visits and the secondary data (Krippendorff, 2018).

\section{Findings}

Revisiting our research questions: "How does Art create value for tourism?", "How do touristic destinations create value for Art? and "How does co-creation occur?" the two cases have both common and different characteristics that can be assessed. The comparative analyses of the case study findings are now discussed.

\subsection{Aims, motivation and expectations of the organizers}

The Zeugma art exhibition is as an art tourism event designed by SAKUDER Art and Culture Association which was founded in 2005 by 11 artists. In order to extend the borders of art in Turkey, SAKUDER organizes art exhibitions, workshops and art and tourism events on national and international platforms. The Association members include well-known artists through to emerging artists and art lovers. The aim of the organizers of the Zeugma Exhibition was to arrange art exhibitions at the cultural heritage site of the Zeugma Mosaic Museum in order to create a unique experience for the artists, who are both the producers of the event through their artwork and consumers of the cultural tourism event. The organizer had drawn on previous experience to realize the event:

As Sakuder, we have organised exhibition tours for artists in Italy and Paris as well as İstanbul. Artist experienced visiting art galleries and the cultural heritage sites together with other artists. This year they painted in Monet's House in Paris and exhibited their artworks in the same place. Zeugma Cultural tour and Exhibition is one of these art and tourism events.

Data collection

\begin{tabular}{|c|c|c|}
\hline Cases & Semi-structured interviews & $\begin{array}{l}\text { Ubservation during site visit anc } \\
\text { exhibition }\end{array}$ \\
\hline \multirow[t]{4}{*}{ Zeugma } & The tourists and other visitors at the site $(n=18)$ & Cultural Heritage Sites \\
\hline & The organizers of the art tourism events in Zeugma and the & The Exhibition Area: Zeugma \\
\hline & managers of the museum $(n=3)$ & Mosaic Museum \\
\hline & $\begin{array}{l}\text { The artists attending the exhibition and the tourism event } \\
(n=20)\end{array}$ & \\
\hline \multirow[t]{4}{*}{ Göbeklitepe } & The visitors in the exhibition area $(n=5)$ & Cultural Heritage Sites \\
\hline & The organizers of the art tourism events in ARMADA & The Exhibition Area: Armada \\
\hline & Shopping Mall and Gallery M $(n=2)$ & Shopping Mall \\
\hline & $\begin{array}{l}\text { The artists attending the exhibition and the tourism event } \\
(n=10)\end{array}$ & \\
\hline
\end{tabular}

\section{artand tourism}

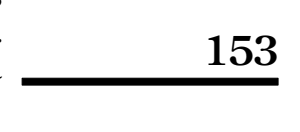


The Zeugma Art Exhibition was organized as part of Gaziantep Culture week and created value for the city and the public as an art event. Using this special week and its related concepts, this extends the value of both the art exhibition and tourism. To acquire more visitors was one of the aims of this art tourism organization. The time and place of the exhibition were a unique combination for the art and tourism event in terms of creating value. The Province Governor of Gaziantep opened the exhibition and the Culture and Tourism Manager of the city explained what happened:

This is where cultural events take place. It was opened in 2011 with a closed area of approximately 30 thousand $\mathrm{m} 2$. In the museum, a three thousand metre squared Mosaic is exhibited.. We had been designing such an exhibition in 2018 since September and then we talked to SAKÜDER. During Gaziantep Tourism Week, we wanted to make an exhibition about the meaning and importance of the day and also highlight the values of Gaziantep. Art and culture came together with that exhibition. It was a great honour for us to host people who have proven themselves in art in our city. We also think that the city will find an echo in the field of tourism with the sound it brings to the culture and tourism, plastic arts, culture. Because many people who came here have never seen Gaziantep.

Similarly, the Göbeklitepe exhibition was organized after 2019 was announced as Göbeklitepe Year, and the aim was to introduce Göbeklitepe to the public with different events. The organizer of the Göbeklitepe Art Exhibition designed it in a central shopping mall in Ankara (Armada) where the shopping mall hosts art in its art gallery and its art corridors all year long using the motto: "art and life together". The gallery manager explained their aim:

...we are trying to create a convenient atmosphere for art, artist and art audience. . .in our gallery and shopping mall bridge corridors. As you know 2019 announced as Göbeklitepe Year and we wanted to attend the promotion activities of Göbeklitepe with this art exhibition. All artists in the exhibition focus [on the] cultural heritage site in their artworks.

\subsection{Visitor experiences and value creation}

As shown in the case comparison table (Table 2), visitors coming to Göbeklitepe exhibition in the shopping mallexperiencedartwork in the same way as itoccurs in the Zeugma museum, which can be considered as an art marketing event in an alternative place. One of the visitors at the Zeugma Exhibition expressed her thoughts, identifying its benefits and also communication limitations:

I am an art teacher in this city but I am not from there. I am really happy to see exhibitions in the Zeugma Mosaic Museum Gallery. It's very important for the city. There are just a few galleries. . . and the city was not open to the art events three years ago. Now I see that the municipality supports art events. I came to the opening because I know the exhibition from my friends. There could be more posters, people does not know that there is an art gallery, but in these ways they learn. We want people to come and perform with us here, spending time and see the texture of the city. These types of events are an advantage for the people living. . .here.

One of the visitors at the Gökbeklitepe Exhibition discussed the anticipated experience:

When I come to this shopping mall I always visit the gallery, my interest and knowledge on art is changed. . .I am expecting to see new exhibitions every time I [come]there. I have seen the poster of the exhibition ... outside and I come here on purpose. I have not visited Göbeklitepe yet but I really want to visit.

The artworks created value relating to the experience of the cultural heritage sites for both those who had already seen there before and for those who had not.

\subsection{Artist experiences and values}

Both Zeugma and Göbeklitepe exhibitions involve the concept of cultural heritage. Artists have linked their style with this concept and the exhibitions created new value with their figurative 
Art exhibition designed from a cultural heritage sites' perspective

Unexpected meeting of art and society

The aims of the events related to both art and tourism

Exhibition in Zeugma Mosaic Museum (near by the

authentic heritage site)

Exhibition in shopping mall in Ankara (far away from the authentic heritage site and close to a high

Exhibition times align with celebrating each site

Gaziantep Culture Week (April 2019)

The city council supported the event during

Gaziantep Culture Week and took part in the opening

and award ceremony

Promotion documents located the city but not in the museum

Artists represented the figurative and abstract forms of the cultural heritage sites in their work through their visits or from secondary information population area in the city centre)

\section{Göbeklitepe Year}

The Cultural Department of Government supported

the event as part of the 2019 Göbeklitepe Year and

arranged the opening ceremony

Large promotion screens were used in the city Case similarities and
differences

and abstract representations. Although the experiences of the artists were individual, it was clear that this connection has made them rethink artistically time and place from the scope of cultural value and heritage sites. Since this was common for the artists for both events, the tourism experience of Zeugma case was an additional value for the artists.

The artist from the Zeugma Exhibition explained the benefits of participating in terms of enhancing creativity and expanding the number of professional contacts:

It was wonderful for an artist to exhibit in the Zeugma Mozaic museum. I designed all my works for Zeugma after deciding be a part of the exhibition with my students. I have never seen Gaziantep before, I also thought that this exhibition is good to see there. It is better to visit these cultural places with an artist group. We become friends, extend our art network and ideas. It was an incredible experience being in there and being together.

An artist in the exhibition explained their artwork in terms of incorporating influences from the cultural site and the role of exhibition:

I was excited when they asked me if I wanted to be a part of the Göbeklitepe Exhibition; even though I have not visited there I have read lots before and I have seen the photographs of course. I match the cultural historical layer with my own style in my work.

The other artist who attended both events noted how previous knowledge about the two sites and their influence in shaping the work in co-creating terms explained how this has been operationalized:

I have seen Zeugma and Göbeklitepe before and connect my works with the concept in an abstract way basing on my memories besides the meaning and values of these universal cultural heritages. I believe that art should be more in life and artists are a part of transferring cultural values to society and the next generations. Both events are important for art and culture in different ways of course and seeing different artists work on a particular concept is a value for the audience.

\subsection{Art and society link: reconnecting with time and place}

The aim of the art exhibitions in the cultural heritage site was to integrate the public with cultural heritage and cultural value through art in a different way to, and in addition to, the other promotion activities. A link between art and culture was created so that the artists 
worked together synergistically. This gave a contemporary look to the history of the sites for 10,3 both the artists and the audience. As mentioned earlier, the artists interpreted the concepts in their own style, and it was a new experience for most of them in terms of adoption of the historical sites concept. Also, the findings show that the artists' relationship with time has the potential to transfer the reconnection experience to the audience.

Our investigation of the Zeugma and Göbeklitepe exhibitions brings to the fore a sense of authenticity and even nostalgia. Even though visitors never experienced its creation first hand, they can still experience a sense of apparent nostalgia.

\subsection{Authenticity and atmosphere in time and place}

Both shopping mall visitors and museum visitors mentioned that they are happy to see the art exhibition. The Göbeklitepe exhibition also has the potential to stimulate them to visit the Göbeklitepe Cultural Heritage site by creating an awareness of authenticity of place. On the other hand, the Zeugma Exhibition creates a new connection in the mind of the museum visitors in terms of time and place authenticity. Reconnecting with authenticity is one of the roles of these art exhibitions in understanding both the changing and shared values via the artworks and the cultural heritage site itself. While the Zeugma Exhibition was held in the art gallery of the mosaic museum, the Göbeklitepe Exhibition was held in a shopping mall in the capital city of Turkey, far away from the cultural heritage site. Thus, the atmosphere here had been deliberately created. This difference then raises issues regarding the authenticity of the sites. While it is still possible to visit the Göbeklitepe as a cultural heritage site, the Zeugma mosaics have been moved to a specially designed museum. Although visitors can experience a sense of the authentic atmosphere in the first case, they need to imagine the original atmosphere at the Zeugma Mosaics Museum.

\subsection{Reconnecting with authenticity: tangible and intangible combinations}

Reconnecting with authenticity also appears through the artworks and the reinterpretation of time, place and cultural value. Some artists created their artworks based on the Zeugma and Göbeklitepe concepts, while other artists participated in the exhibition with their earlier works (See Plate 5 and Plate 6). Even the artists who did not directly present the Zeugma and Göbeklitepe concepts in an obvious way in their artwork said that they had chosen their works so that they combined with the exhibition in a sophisticated way. The figurative style of the context created a sense of contemporary tangibility of the cultural value among the artists and audience. Abstract art, on the other hand, has the potential to create some intangible dimensions in reconnecting with the concept in a flexible and unimpaired. The combination of tangible/obvious/figurative and intangible/ambiguous/ abstract characteristics of the artworks resulted in the creation of an emotional experience. From an art and tourism co-creation perspective, art has a role to play in helping to attract potential visitors by spreading awareness about the cultural heritage sites. When we consider the influence of cultural heritage sites on art, we can see similar potential through the generation of awareness of art in these cultural arenas. Since art is a subset of culture, those who are interested in culture and history also have the potential to be interested in art. While art works for cultural tourism, the cultural heritage concept and tourism work as an arts marketing tool, so they are mutually supportive.

\section{Discussion}

Since the aim of this paper was to gain insight into the link between art and tourism from a value co-creation perspective through art exhibitions and events (Gronroos, 2012), the ideal way to gather data was to secure the opinions of the people involved. The interaction with others on-site is a co-created tourism experience (Campos et al., 2008). We assessed the gaps in 

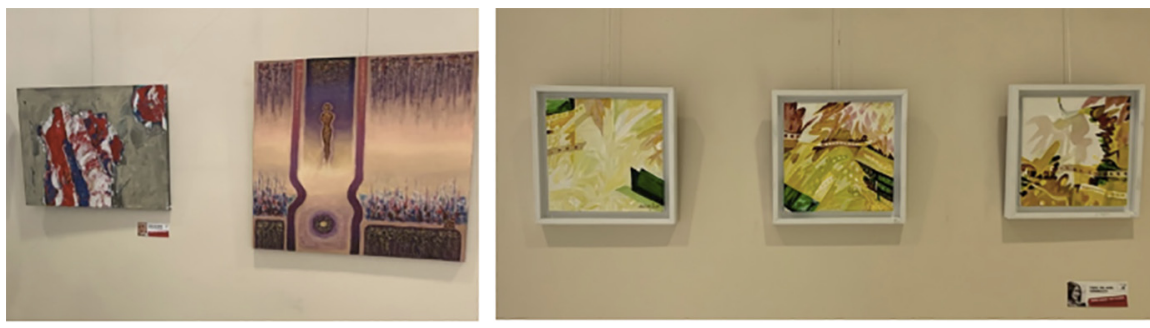

$\mathrm{B}=$
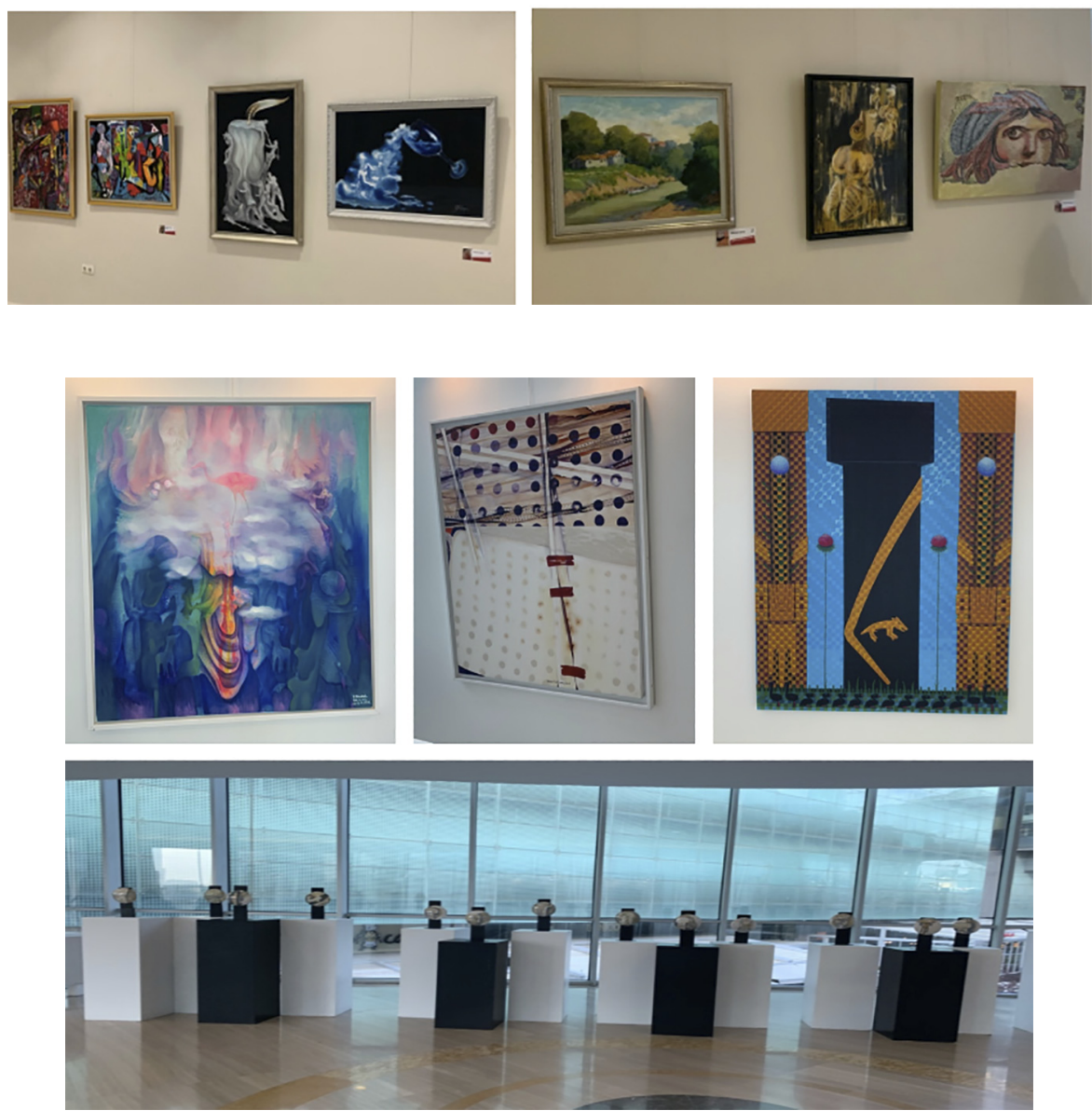

knowledge and identified the future opportunities for art tourism theory development and practice. As we have stressed in the literature and the findings, these cases serve as evidence of current practices of co-creation through the scope of art, tourism, time, place and authenticity (Ramkissoon and Uysal, 2014). These relate to Throsby's (2003) interpretations of what comprises culture value: aesthetic properties, symbolic meaning, history, artistic trends, authenticity, integrity and uniqueness. Additionally, reconnecting with time and
Insights into link between art and tourism

Plate 5.

Some artworks from the Zeugma exhibition
Plate 6.

Some artworks from the Göbeklitepe exhibition 
AAM 10,3

158 place as well as art and culture is essential for maintaining the link between art and society. These types of events have a significant role to play for both the individuals who experienced it and society (Crossick and Kaszynska (2014). Art tourism in cultural heritage sites as in the Zeugma case, or art for creating awareness of cultural tourism as in the Göbeklitepe case, represents the coordination of art and cultural heritage in terms of cultural value and its intrinsic, instrumental and institutional elements (Holden, 2006). The events create a subjective experience of culture in intellectual, emotional and spiritual terms for both visitors and artists (Kaszynska, 2015). The art and tourism case (Zeugma) creates both social and economic value in the industry in addition to the art in the shopping mall case (Göbeklitepe). Finally, institutional value impacts on the public through the organizations involved. When we consider these values in practice, we have revealed a range of common and different aspects of the art-tourism relationship in terms of cultural value, art tourism and arts marketing. Figure 2 visualizes this relationship, together with the gaps as opportunities for future art, culture and tourism policy development.

As mentioned in Table 2 before, the two cases are similar in terms of the unexpected meeting of art and society. $\mathrm{C} 1$ and $\mathrm{C} 2$ are considered in terms of place as a product and the promotion activities of arts marketing and cultural tourism. $\mathrm{Cl}$ is the art tourism event for artists relating to the art exhibition in the Zeugma Museum. On the other hand, this exhibition is an ongoing art tourism event that the tourists visiting the Zeugma Mosaic Museum suddenly came face to face with. C2 is a conceptual art exhibition to promote the Göbeklitepe cultural heritage site. While

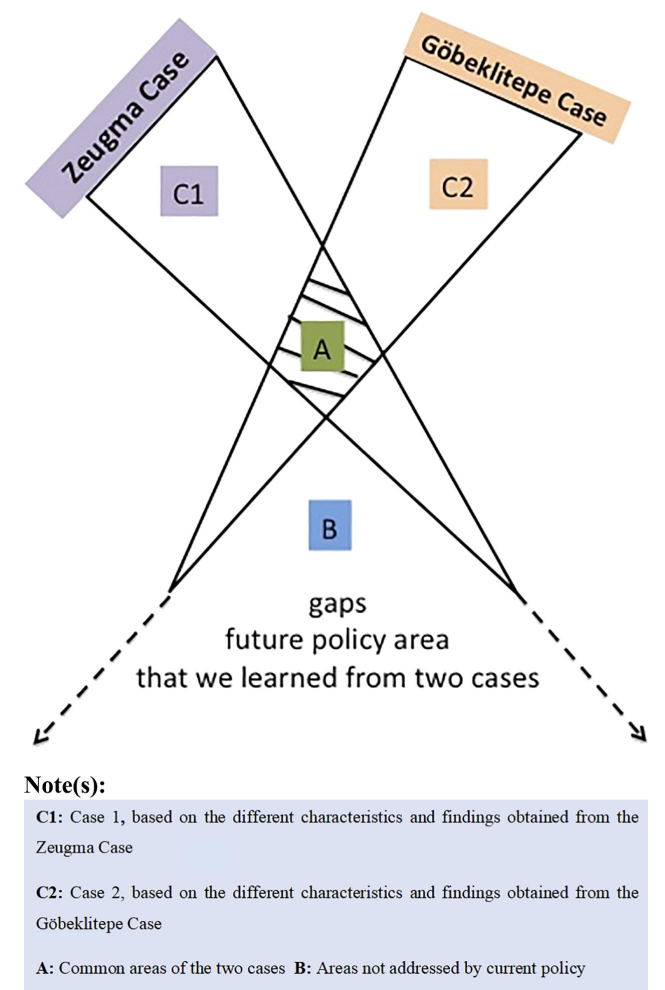

Figure 2.

The gaps and the future opportunities for art tourism theory and practice 
artists created for the Göbeklitepe exhibition, visitors at the mall who come there both for the Göbeklitepe events and for shopping suddenly experience the art exhibition.

The gaps identified in the case study analysis have the potential to help shape future practices (marked as B) considered in terms of the promotion signs, authenticity of the atmosphere and the artistic process.

C2 has better promotion in a mall in Ankara and the street screens are effectively used. C1 has a better placement near the museum, but the signs are not sufficient in terms of directing people to the art gallery. The atmosphere is more that of a modern art gallery, which does not totally match with the mosaic museum's authenticity. Authenticity in the production of artworks can be accomplished by creating an environment that enables visitors to experience the cultural heritage sites in a more authentic way, for example, via live art performances or workshops at the cultural heritage sites.

\section{Conclusions, implications, limitations and future directions}

The paper demonstrates that the new experiences and new niche tourism activities such as art tourism are emergent areas. The findings of the study relate to the role of the co-creation process in arts marketing. Marketing art in alternative places creates value in closing the gap between art and society through the use of related fields such as culture and heritage. In terms of cultural value, the paper identifies the reconnection with cultural heritage through contemporary art. This is a way of looking at culture and its concepts in terms of different time and place dimensions that make visitors more engaged with culture and contemporary reflection of it through art.

The two cases are discussed here demonstrate the relationship between cultural heritage and art. While we recognize the different art tourism practices, the co-creation process of two different concepts is used to expand our understanding regarding the art and society link in terms of arts marketing. Art and culture come together in societal terms. We now suggest some practical implications for future development in the art and tourism industry:

(1) Creating a space for contemporary art in cultural heritage museums in order to promote art to wider society. This is based on the idea that art is a part of culture and the museum audience is an important potential consumer of art from a market generation perspective.

(2) Creating awareness of art and cultural tourism in cities, and other populated areas, and cultural heritage sites by using relevant strategic timings (such as city culture week) in addition to using common popular places (such as shopping malls).

(3) On the other hand, contemporary art has the potential to connect time and culture with the society in a creative way. This implication relates to using contemporary art in cultural heritage sites in order to create some contemporary connections and perceptions in the minds of visitors.

(4) Finally, art and cultural tourism have the potential to support each other and create value together.

Our study contributes to the value co-creation literature through the art/tourism lens while our implications shed light on art and tourism industry theory and practice. The gaps in theory and practice which we have identified have helped to create future opportunities for art tourism.

The two cases assessed in this paper demonstrate the relationship between art and tourism, but this relationship analysed so far is limited to cultural heritage tourism and art exhibitions related with cultural heritage sites in Turkey. The findings, however, have 
potential to provide comparative insight for future qualitative research elsewhere, as well as 10,3 informing industry practice. Quantitative insight would also be helpful in terms of generating wider and statistically testable claims concerning the relationships discussed in this paper.

\section{References}

American Marketing Association (2004), "Definition”, Marketing News, September 15, 2004.

Andrades, L. and Dimanche, F. (2014), "Co-creation of experience value: a tourist behaviour approach", in Chen, M. and Uysal, J. (Eds), Creating Experience Value in Tourism, CABI, London, pp. 95-112, doi: 10.1079/9781780643489.0095.

Arnould, E.J., Price, L.L. and Malshe, A. (2006), "Toward a cultural resource-based theory of the customer", The Service-Dominant Logic of Marketing: Dialog, Debate and Directions, Armonk, NY, ME Sharpe, pp. 320-333.

Bendpudi, N. and Leone, R.P. (2003), "Psychological implications of customer participation in co-production", Journal of Marketing, Vol. 67 No. 1, pp. 14-28.

Benjamin, W. (1970/1936), "The work of art in the age of mechanical reproduction”, in (trans.) Zhan, H. (Ed.), Illuminations: Essays and Reflections, Jonathan Cape, London, pp. 219-253.

Benjamin, W. (1999), The Arcades Project, Harvard University Press, Cambridge, MA, p. 447.

Bertella, G. (2014), "The co-creation of animal-based tourism experience", Tourism Recreation Research, Vol. 39 No. 1, pp. 115-125.

Binkhorst, E. and Den Dekker, T. (2009), "Agenda for co-creation tourism experience research", Journal of Hospitality Marketing and Management, Vol. 18 Nos 2-3, pp. 311-327.

Bitner, M.J. (1992), "Servicescapes: the impact of physical surroundings on customers and employees", Journal of Marketing, Vol. 56 No. 2, pp. 57-71.

Björkman, I. (2002), "Aura: aesthetic business creativity”, Consumption, Markets and Culture, Vol. 1, pp. 69-78.

Bonus, H. and Ronte, D. (1997), "Credibility and economic value in the visual arts", Journal of Cultural Economics, Vol. 21 No. 2, pp. 103-118.

Boyatzis, R.E. (1998), Transforming Qualitative Information: Thematic Analysis and Code Development, Sage, London.

Brown, S. (1999), "Retro-marketing: yesterday's tomorrows, today!", Marketing Intelligence and Planning, Vol. 17 No. 7, pp. 363-376.

Campos, A.C., Mendes, J., Valle, P.O.D. and Scott, N. (2018), "Co-creation of tourist experiences: a literature review", Current Issues in Tourism, Vol. 21 No. 4, pp. 369-400.

Crossick, G. and Kaszynska, P. (2014), "Under construction: towards a framework for cultural value", Cultural Trends, Vol. 23 No. 2, pp. 120-131.

Dann, G. (1998), "There's no business like old business: tourism, the nostalgia industry of the future", Global Tourism, Vol. 2, pp. 29-43.

Dorrian, M. (2014), "Museum atmospheres: notes on aura, distance and affect", The Journal of Architecture", Vol. 19 No. 2, pp. 187-201.

Eco, U. (1977), Das Offene Kunstwerk, Gabler, Wiesbaden.

Eisenhardt, K.M. (1989), "Building theories from case study research", Academy of Management Review, Vol. 14 No. 4, pp. 532-550.

Fabricius, M.P. (2001), Competitive Strategies for Tourism Destinations, Doctoral dissertation, University of South Africa.

Franklin, A. (2018), "Art tourism: a new field for tourist studies", Tourist Studies, Vol. 18 No. 4, pp. 399-416. 
Fusch, P.I. and Ness, L.R. (2015), "Are we there yet? Data saturation in qualitative research", The Qualitative Report, Vol. 20 No. 9, p. 1408.

Goulding, C. (1999), "Heritage, nostalgia and the 'grey' consumer", Journal of Marketing Practice: Applied Marketing Science, Vol. 5 Nos 6/8, pp. 177-199.

Gronroos, C. (2012), "Conceptualising value co-creation: a journey to the 1970s and back to the future", Journal of Marketing Management, Vol. 28 Nos 13/14, pp. 1520-1534.

Holbrook, M.B. (1993), "Nostalgia and consumption preferences: some emerging patterns of consumer tastes", Journal of Consumer Research, Vol. 20 No. 2, pp. 245-256.

Holbrook, M.B. (2006), "Consumption experience, customer value, and subjective personal introspection: an illustrative photographic essay", Journal of Business Research, Vol. 59 No. 6, pp. 714-725.

Holbrook, M.B. and Schindler, R.M. (1991), "Echoes of the dear departed past: some work in progress on nostalgia”, in Holman, R.H. and Solomon, M.R. (Eds), Advances in Consumer Research, Association for Consumer Research, Provo, UT, Vol. 18, pp. 330-333.

Holden, J. (2006), Cultural Value and the Crisis of Legitimacy, DEMOS, London.

Jafari, A. and Taheri, B. (2013), "Nostalgia, reflexivity and the narratives of self: reflections on Devine's 'Removing the rough edges"', Consumption, Markets and Culture, Vol. 17 No. 2, pp. 215-230.

Kaszynska, P. (2015), "Capturing the vanishing point: subjective experiences and cultural value", Cultural Trends, Vol. 24 No. 3, pp. 256-266.

Kim, S. (2012), "Audience involvement and film tourism experiences: emotional places, emotional experiences", Tourism Management, Vol. 33 No. 2, pp. 387-396.

Krippendorff, K. (2018), Content Analysis: An Introduction to its Methodology, Sage, London.

Levi-Strauss, C. (1969), Introduction to a Science of Mythology, Jonathan Cape, London.

Lin, Z., Chen, Y. and Filieri, R. (2017), "Resident-tourist value co-creation: the role of residents' perceived tourism impacts and life satisfaction", Tourism Management, Vol. 61, pp. 436-442.

Lusch, R.F. and Vargo, S. (2006), "Service dominant logic: reactions, reflections and refinements", Marketing Theory, Vol. 6 No. 3, pp. 281-288.

Lusch, R.F. and Vargo, S.L. (2014), Evolving to a New Dominant Logic for Marketing” in the ServiceDominant Logic of Marketing, Routledge, Oxford, pp. 21-46.

MacCannell, D. (1976), The Tourist; A New Theory of the Leisure Class, Stoken Books, New York.

McGarry, D. (1998), "Redefining value through innovation”, Electronic Publishing, Vol. 22 No. 9, p. 50.

MacLeod, N. (2006), "Cultural tourism: Aspects of authenticity and commodification", in Smith, M. and Robinson, M. (Eds), Cultural Tourism in a Changing World: Politics, Participation and (Re) Presentation, Channel View, Tonawanda, NY, pp. 177-190.

Newman, G.E., Diesendruck, G. and Bloom, P. (2011), “Celebrity contagion and the value of objects", Journal of Consumer Research, Vol. 38 No. 2, pp. 215-228.

Norman, R. and Ramirez, R. (1998), Designing Interactive Strategy: From Value Chain to Value Constellation, Wiley, Chichester.

O'Brien, D. and Lockley, P. (2015), "The social life of cultural value", Making Culture Count, Palgrave Macmillan, London, pp. 87-103.

Pongsakornrungsilp, S. and Schroeder, J.E. (2011), "Understanding value co-creation in a coconsuming brand community”, Marketing Theory, Vol. 11 No. 3, pp. 303-324.

Porter, M. (1985), The Value Chain and Competitive Advantage, Chapter 2 in Competitive Advantage: Creating and Sustaining Superior Performance, Free Press, New York, pp. 33-61.

Porter, M.E. (1990), "New global strategies for competitive advantage", Planning Review, Vol. 18 No. 3, pp. 4-14. 
Prahalad, C.K. and Ramaswamy, V. (2004), "Co-creation experiences: the next practice in value creation"”, Journal of Interactive Marketing, Vol. 18 No. 3, pp. 5-14.

Prebensen, N.K. and Foss, L. (2011), "Coping and co-creating in tourist experiences", International Journal of Tourism Research, Vol. 13 No. 1, pp. 54-67.

Ramkissoon, H. and Uysal, M. (2014), "Authenticity as a value co-creator of tourism experiences", in Prebensen, N.K., Chen, J.S. and Uysal, M. (Eds), Creating Experience Value in Tourism, CABI, Wallingford, pp. 113-124.

Reichenberger, I. (2017), “C2C value co-creation through social interactions in tourism”, International Journal of Tourism Research, Vol. 19 No. 6, pp. 629-638.

Richards, G. (Ed.), (2007), Cultural Tourism: Global and Local Perspectives, Psychology Press, New York.

Richards, G. (2018), "Cultural tourism: a review of recent research and trends", Journal of Hospitality and Tourism Management, Vol. 36, pp. 12-21.

Rickly-Boyd, J.M. (2012), "Authenticity and aura: a Benjaminian approach to tourism", Annals of Tourism Research, Vol. 39 No. 1, pp. 269-289.

Rosenberg, J.P. and Yates, P.M. (2007), "Schematic representation of case study research designs", Journal of Advanced Nursing, Vol. 60 No. 4, pp. 447-452.

Sandström, S., Edvardsson, B., Kristensson, P. and Magnusson, P. (2008), "Value in use through service experience”, Managing Service Quality: An International Journal, Vol. 18 No. 2, pp. 112-126.

Schouten, F. (2007), "Cultural tourism: between authenticity and globalization", Cultural tourism: Global and local perspectives, pp. 25-37.

Seawright, J. and Gerring, J. (2008), "Case selection techniques in case study research: a menu of qualitative and quantitative options", Political Research Quarterly, Vol. 61 No. 2, pp. 294-308.

Sharma, G. (2017), "Pros and cons of different sampling techniques", International Journal of Applied Research, Vol. 3 No. 7, pp. 749-752.

Sheth, J.N. and Uslay, C. (2007), "Implications of the revised definition of marketing: from exchange to value creation", Journal of Public Policy and Marketing, Vol. 26 No. 2, pp. 302-307.

Sheth, J.N., Sisodia, R.S. and Sharma, A. (2000), "The antecedents and consequences of customercentric marketing", Journal of the Academy of Marketing Science, Vol. 28 No. 1, pp. 55-66.

Silverman, D. (Ed.) (2016), Qualitative Research, Sage, London.

Solveig, W. (1996), "The customer as co-producer", European Journal of Marketing, Vol. 30 No. 4, pp. 6-17.

Tajzadeh-Namin, A. (2012), "A review on value creation in tourism industry", Management Science Letters, Vol. 2 No. 1, pp. 203-212.

Throsby, D. (2003), "Determining the value of cultural goods: how much (or how little) does contingent valuation tell us?", Journal of Cultural Economics, Vol. 27 Nos 3/4, pp. 275-285.

Tribe, J. (2008), "The art of tourism", Annals of Tourism Research, Vol. 35 No. 4, pp. 924-944.

Vargo, S.L. and Lusch, R.F. (2004), "Evolving to a new dominant logic for marketing", Journal of Marketing, Vol. 68 No. 1, pp. 1-17.

Vargo, S.L. and Lusch, R.F. (2017), "Service-dominant logic 2025", International Journal of Research in Marketing, Vol. 34 No. 1, pp. 46-67.

Walker, J.A. and Chaplin, S. (1997), Visual Culture: An Introduction, Manchester University Press, Manchester.

Yin, R.K. (2014), Case Study Research: Design and Methods (Applied Social Research Methods), Sage Publications, Thousand Oaks, CA. 


\begin{abstract}
About the authors
Özge Gökbulut Özdemir has carried out research on the art industry, art entrepreneurship and the contributions of art to business. She handles themes such as consumption culture, technology and alienation in the context of individual versus environment. She is also a visual artist and her works have been exhibited in more than 30 national and international exhibitions. She is working on art industry projects at Liverpool John Moores University as a visiting scholar and is also associate professor at Ankara Yildirim Beyazit University in Turkey.

Ian Fillis is a leading entrepreneurial small business researcher, with other research interests in creativity, arts marketing and consumer research. He has been visiting distinguished thought leader at the University of South Australia, University of Tasmania distinguished visitor and the Bowater visiting research fellow, Deacon University. He is also the editor of the forthcoming Edward Elgar Handbook on Marketing and Entrepreneurship. Ian Fillis is the corresponding author and can be contacted at: I.R.Fillis@ljmu.ac.uk

Ayşe Baş Collins is associate professor at the School of Applied Technology and Management at Bilkent University, Turkey. She has research expertise in education and tourism-related fields. She is also a visiting scholar at the University of South Australia.
\end{abstract}

For instructions on how to order reprints of this article, please visit our website: 